\title{
Standardisation of Pre Hardening and Hardening Techniques for In vitro Derived Plantlets of Orchid and
}

\section{Anthurium}

\section{Selvaraj VKS ${ }^{1 *}$ and Bharathi $\mathrm{A}^{2}$}

1Department of Horticulture, Coconut Research Station, Tamil Nadu Agricultural University (TNAU), India

${ }^{2}$ Department of Plant Breeding and genetics, Agricultural Research Station, India

\section{Research Article}

Volume 3 Issue 2

Received Date: February 19, 2018

Published Date: March 20, 2018

Corresponding author: Vijai Selvaraj KS, Department of Horticulture, Coconut Research Station, Tamil Nadu Agricultural University (TNAU), India, Tel: +91-4373-260205; E-mail: ksvijayselvaraj@gmail.com

\section{Abstract}

In laboratory for Orchid subcultures pre hardening treatments with $1 / 2 \mathrm{MS}$ media + NAA $8 \mathrm{mg} / \mathrm{l}$ as standard media and growing media compositions like Leaf mould + Charcoal (1:1), Leaf mould + Charcoal + Brick (1:1:1), Leaf mould + Coco peat + Charcoal (1:1:1), Leaf mould + Brick + Coco peat (1:1:1) and Charcoal + Brick + Coco peat (1:1:1) as Control for prehardening and the same above growing media without sterilization had been practiced under shade net for hardening and in Anthurium laboratory treatments comprised of $1 / 2$ MS media + NAA $2 \mathrm{mg} / \mathrm{l}$ as standard media and growing media compositions like Leaf mould + Saw dust (1:1),Leaf mould + Coco peat + Charcoal (1:1:1), Leaf mould + Coir pith (1:1),Leaf mould + Coir pith + Coco peat (1:1:1),Saw dust + Coir pith + Coco peat (1:1:1), Leaf mould + Coco peat (1:1) as Control for prehardening and the same above growing media without sterilization had been practiced under shade net for hardening Maximum survival percentage was observed in $\mathrm{T}_{2}$ (Leaf mould + Charcoal + Brick (1:1:1) and Leaf mould + Coco peat + Charcoal (1:1:1) both in Orchid and Anthurium respectively. The number of leaves were highest in $\mathrm{T}_{5}(5.81$ and 26.03) and number of roots i.e., 10.77 and 23.9 / plant were higher in medium containing Charcoal + Brick + Coco peat (1:1:1) i.e., as control. The root and shoot length were recorded higher in $\mathrm{T}_{2}$ (Leaf mould + Charcoal + Brick (1:1:1)) as $6.11 \mathrm{~cm}$ and $16.77 \mathrm{~cm}$ and $4.48 \mathrm{~cm}$ and $20.47 \mathrm{~cm}$ in laboratory and in shade net respectively. The survival percent was enhanced in $\mathrm{T}_{2}$ as $92.43 \%$ and $91.53 \%$ in laboratory and field. Higher no. of leaves and plant height were observed in $\mathrm{T}_{2}$ (Leaf mould + Coco peat + Charcoal (1:1:1)) followed by $\mathrm{T}_{6}$ (Leaf mould + Coco peat (1:1)) [Control].The plantlets in $\mathrm{T}_{2}$ established well in terms of plant height in laboratory and in shade net $(6.17 \mathrm{~cm}$ and $31.4 \mathrm{~cm})$ and number of new shootlets (Plantlet (2.67 and 7.67)). The number of leaves were highest in $\mathrm{T}_{2}$ (12.33 and 20.67) and number of roots i.e., 3.33 and 8.33 / plant were higher in medium containing Leaf mould + Coco peat + Charcoal (1:1:1) followed by control 


\section{Open Access Journal of Agricultural Research}

i.e., $\mathrm{T}_{6}$ (Leaf mould + Coco peat (1:1)).The root length was also recorded higher in $\mathrm{T}_{2}$ (Leaf mould + Coco peat + Charcoal (1:1:1)) as $4.3 \mathrm{~cm}$ and $15.67 \mathrm{~cm}$ (Table 13 ) in laboratory and in shade net respectively.

Keywords: Shoot lets; MS media; IAA, NAA; Prehardening; Hardening; Shade net; Survival rate

\section{Introduction}

Taxonomically orchids represent the most highly evolved family among monocotyledons with approximately 750 genera and 22,000 and 30,000 species and over 74,400 natural and manmade hybrids. And thus orchids had a potential growth in every day cut flower trade. In Thailand $92 \%$ of cut flowers comprises of Dendrobium orchids only. Anthurium andreanum Lind is cultivated for its colorful long lasting flowers, has gained importance as a major cut flower of the modern world. In this regard the media for orchids and anthurium is not being standardized preciously particularly before hardening chamber with different growing medias. Thus this study aims to develop the technique for pre hardening and hardening through media standardization of orchid and anthurium.

\section{Materials and Methods}

\section{Technical programme}

Crops: $\quad$ 1. Orchid (Dendrobium) hybrid Sonia-17

2. Anthuirum (Anthurium andreanum) var, Temptation

\section{Treatment Details}

\section{Pre hardening treatments \\ A. Orchid (In laboratory) \\ Media $\rightarrow 1 / 2$ MS media + NAA $8 \mathrm{mg} / \mathrm{l}$ \\ $\mathrm{T}_{1} \quad$ - $\quad$ Leaf mould + Charcoal (1:1) \\ $\mathrm{T}_{2} \quad$ - $\quad$ Leaf mould + Charcoal + Brick (1:1:1) \\ $\mathrm{T}_{3} \quad$ - $\quad$ Leaf mould + Coco peat + Charcoal \\ $(1: 1: 1)$ \\ $\mathrm{T}_{4} \quad-\quad$ Leaf mould + Brick + Coco peat (1:1:1) \\ $\mathrm{T}_{5} \quad-\quad$ Charcoal + Brick + Coco peat $(1: 1: 1)$ \\ [Control]}

\section{B. Anthurium (In laboratory)}

Media $\rightarrow 1 / 2$ MS media + NAA $2 \mathrm{mg} / \mathrm{l}$

$\mathrm{T}_{1} \quad-\quad$ Leaf mould + Saw dust (1:1)

$\begin{array}{lll}\mathrm{T}_{2} & - & \text { Leaf mould + Coco peat + Charcoal } \\ (1: 1: 1) & & \\ \mathrm{T}_{3} & - & \text { Leaf mould + Coir pith (1:1) } \\ \mathrm{T}_{4} & - & \text { Leaf mould + Coir pith + Coco peat } \\ (1: 1: 1) & & \\ \mathrm{T}_{5} & - & \text { Saw dust + Coir pith + Coco peat (1:1:1) } \\ \mathrm{T}_{6} & - & \text { Leaf mould + Coco peat (1:1) [Control] }\end{array}$

\section{Hardening treatments (Under shade net)}

A. Orchid

$\mathrm{T}_{1} \quad$ - $\quad$ Leaf mould + Charcoal (1:1)

$\mathrm{T}_{2} \quad$ - $\quad$ Leaf mould + Charcoal + Brick (1:1:1)

$\mathrm{T}_{3} \quad$ - $\quad$ Leaf mould + Coco peat + Charcoal

(1:1:1)

$\mathrm{T}_{4} \quad$ - $\quad$ Leaf mould + Brick + Coco peat (1:1:1)

$\mathrm{T}_{5} \quad-\quad$ Charcoal + Brick + Coco peat $(1: 1: 1)$

[Control]

\section{B. Anthurium}

$\mathrm{T}_{1} \quad-\quad$ Leaf mould + Saw dust (1:1)

$\mathrm{T}_{2} \quad$ - $\quad$ Leaf mould + Coco peat + Charcoal

$(1: 1: 1)$

$\mathrm{T}_{3} \quad$ - $\quad$ Leaf mould + Coir pith (1:1)

$\mathrm{T}_{4} \quad$ - $\quad$ Leaf mould + Coir pith + Coco peat

(1:1:1)

$\mathrm{T}_{5} \quad$ - $\quad$ Saw dust + Coir pith + Coco peat $(1: 1: 1)$

$\mathrm{T}_{6} \quad-\quad$ Leaf mould + Coco peat (1:1) [Control]

Replication: 3

Design: FCRD

\section{Results and Discussion}

\section{Orchid}

The survival percent was enhanced in $\mathrm{T}_{2}$ followed by control (Table 1). 


\section{Open Access Journal of Agricultural Research}

\begin{tabular}{|c|c|c|c|c|}
\hline Treatments & \multicolumn{2}{|c|}{ Stages } & \multicolumn{2}{c|}{ Stages } \\
\hline & Under laboratory condition & Under shade net & Under laboratory condition & Under shade net \\
\hline $\mathrm{T}_{1}$ & 85.41 & 83.43 & 1.25 & 5.7 \\
\hline $\mathrm{T}_{2}$ & 92.93 & 91.27 & 1.78 & 7.4 \\
\hline $\mathrm{T}_{3}$ & 65.72 & 63.01 & 1.27 & 5.17 \\
\hline $\mathrm{T}_{4}$ & 58.13 & 56.17 & 0.96 & 6.57 \\
\hline $\mathrm{T}_{5}$ & 91.7 & 90.63 & 1.76 & 5.787 \\
\hline Mean & 78.72 & 76.97 & 1.406 & 0.6125 \\
\hline SE (d) & 8.3544 & 8.179 & 0.1507 & 1.3647 \\
\hline CD (at 5\%) & 18.6149 & 18.2239 & 0.3358 & \\
\hline
\end{tabular}

Table 1: Effect of prehardening and hardening of media on the survival percent and number of new shootlets in vitro derived plantlets of Orchid variety Sonia-17.

This may be due to the process of acclimatization of the plant lets to the hardening media in the in vitro condition itself. The transplantation shock was lesser in the hardening media for the prehardened plantlets that the control plants and hence they survived better [1]. The plantlets in this media established well in terms of plant height in laboratory and in shade net $(7.15 \mathrm{~cm}$ and 33.13 $\mathrm{cm}$ ) (Table 2) and number of new shootlets (Plantlet (1.78 and 7.4)) at laboratory and shade net condition (Table 1) [2].

\begin{tabular}{|c|c|c|c|c|}
\hline Treatments & \multicolumn{2}{|c|}{ Stages } & \multicolumn{2}{c|}{ Stages } \\
\hline & Under laboratory condition & Under shade net & Under laboratory condition & Under shade net \\
\hline $\mathrm{T}_{1}$ & 5.37 & 24.67 & 8.88 & 17 \\
\hline $\mathrm{T}_{2}$ & 7.15 & 33.13 & 10.77 & 23.9 \\
\hline $\mathrm{T}_{3}$ & 5.95 & 27.47 & 8.1 & 16.77 \\
\hline $\mathrm{T}_{4}$ & 4.56 & 22.7 & 6.58 & 13.4 \\
\hline $\mathrm{T}_{5}$ & 6.8 & 30.11 & 10.39 & 23.3 \\
\hline Mean & 5.971 & 27.775 & 8.9533 & 18.892 \\
\hline SE (d) & 0.6317 & 2.9288 & 0.9483 & 2.0187 \\
\hline CD (at 5\%) & 1.4074 & 6.5258 & 2.113 & 4.4979 \\
\hline
\end{tabular}

Table 2: Effect of prehardening and hardening of media on the plant height and number of roots of in vitro derived plantlets of Orchid variety Sonia-17

However the number of leaves were highest in $\mathrm{T}_{5}(5.81$ and 26.03) and number of roots i.e., 10.77 and 23.9 /plant were higher in medium containing Charcoal + Brick + Coco peat (1:1:1) i.e., as control and it was closely followed by $\mathrm{T}_{2}$ (Leaf mould + Charcoal + Brick (1:1:1))
The root and shoot length were recorded higher in $\mathrm{T}_{2}$ (Leaf mould + Charcoal + Brick (1:11:1)) a $6.11 \mathrm{~cm}$ and $16.77 \mathrm{~cm}$ and $4.48 \mathrm{~cm}$ and $20.47 \mathrm{~cm}$ in laboratory and in shade net respectively (Table 3 ).

\begin{tabular}{|c|c|c|c|c|}
\hline Treatments & \multicolumn{2}{|c|}{ Stages } & \multicolumn{2}{c|}{ Stages } \\
\hline & Under laboratory condition & Under shade net & Under laboratory condition & Under shade net \\
\hline $\mathrm{T}_{1}$ & 4.57 & 20.81 & 4.68 & 12.73 \\
\hline $\mathrm{T}_{2}$ & 5.81 & 26.03 & 6.11 & 16.77 \\
\hline $\mathrm{T}_{3}$ & 5.18 & 22.7 & 4.11 & 13.5 \\
\hline $\mathrm{T}_{4}$ & 3.72 & 19.17 & 2.47 & 11.5 \\
\hline $\mathrm{T}_{5}$ & 5.45 & 24.8 & 5.86 & 15.6 \\
\hline Mean & 4.95 & 22.7253 & 4.65 & 14.0327 \\
\hline SE (d) & 0.5224 & 2.3877 & 0.5041 & 0.2239 \\
\hline CD (at 5\%) & 1.164 & 5.3201 & 1.1232 & 0.5164 \\
\hline
\end{tabular}

Table 3: Effect of prehardening and hardening of media on number of leaves and root lengths of in vitro derived plantlets of Orchid variety Sonia-17. 


\section{Open Access Journal of Agricultural Research}

Epiphytic orchids generally need good aeration this is because in their natural habitat they are tree dwellers with roots hanging in the air. In order to provide paper aeration than the potting mixture must be porous which allows excess water to drain off but at the same time must be able to soak up and the retain moisture without sogging. The better establishment of plantlets in leaf mould + charcoal + brick $(1: 1: 1)$ followed by charcoal + brick + cocopeat $(1: 1: 1)$ medium may be due to the maintenance of better micro environment with optimum humidity and aeration compared to the other potting mixtures [3]. The reason for the maintenance of optimum humidity and moisture retention was due to the addition of leaf mould. In the present study the survival and establishment rate remained. Comparatively low in leaf mould + cocopeat + charcoal (1:1:1). However Sharma and Tandon (1992) [4] reported better survival of plantlets of dendrobium sp. In earthen pots containing charcoal + brick pits and coconut fibre (Table 4).

\begin{tabular}{|c|c|c|}
\hline \multirow{2}{*}{ Treatments } & \multicolumn{2}{|c|}{ Stage } \\
\cline { 2 - 3 } & Under laboratory condition & Under shade net \\
\hline $\mathrm{T}_{1}$ & 4.68 & 12.73 \\
\hline $\mathrm{T}_{2}$ & 6.11 & 16.77 \\
\hline $\mathrm{T}_{3}$ & 4.11 & 13.5 \\
\hline $\mathrm{T}_{4}$ & 2.47 & 11.5 \\
\hline $\mathrm{T}_{5}$ & 5.86 & 15.6 \\
\hline Mean & 4.65 & 14.0327 \\
\hline SE(d) & 0.5041 & 0.2239 \\
\hline CD (at $5 \%)$ & 1.1232 & 0.5164 \\
\hline
\end{tabular}

Table 4: Effect of prehardening and hardening of media on root length of in vitro derived plantlets of Orchid variety Sonia $-17$.

Spraying of $1 / 2$ MS nutrient solution resulted in better establishment of plantlets. But there was a non-significant interaction between the pot mixture and nutrient solution spray on the establishment of plantlets. The reduced survival of the plantlets during hardening was resulted because of the shock due to the physiological changes during the sudden transition. However the solution of the medium in which the plantlets have been maintained, have minimized the shock and supported the establishment of the plantlets.

\section{Anthurium}

The survival percent was enhanced in $\mathrm{T}_{2}$ as $92.43 \%$ and $91.53 \%$ in laboratory and in shade net followed by control (Table 5).

\begin{tabular}{|c|c|c|c|c|}
\hline Treatments & \multicolumn{2}{|c|}{ Stages } & \multicolumn{2}{c|}{ Stages } \\
\hline & Under laboratory condition & Under shade net & Under laboratory condition & Under shade net \\
\hline $\mathrm{T}_{1}$ & 47.87 & 45.87 & 3.8 & 17.3 \\
\hline $\mathrm{T}_{2}$ & 92.43 & 91.53 & 6.17 & 31.4 \\
\hline $\mathrm{T}_{3}$ & 65.58 & 64.47 & 5.2 & 25.7 \\
\hline $\mathrm{T}_{4}$ & 87.48 & 85.43 & 4.8 & 20.5 \\
\hline $\mathrm{T}_{5}$ & 84.67 & 83 & 3.8 & 17.16 \\
\hline Mean & 90.49 & 89.2 & 5.9 & 28.2 \\
\hline SE (d) & 78.1644 & 76.709 & 4.9489 & 23.4017 \\
\hline CD (at 5\%) & 8.3333 & 8.1877 & 0.1065 & 0.6217 \\
\hline
\end{tabular}

Table 5: Effect of prehardening and hardening of media on the survival percent and plant height of in vitro derived plantlets of Anthurium variety Temptation.

This may be due to the process of acclimatization of the plantlets to the hardening media and addition of NAA of 1 $\mathrm{mg} / \mathrm{l}$ as the standard one which enhances the better rooting in the in vitro condition itself. The transplantation shock was lesser in the hardening media for the prehardened plantlets that the control plants and hence they survived better [5]. The survival percent was higher in $\mathrm{T}_{2}$ followed by $\mathrm{T}_{6}$. Higher no. of leaves and plant height 


\section{Open Access Journal of Agricultural Research}

were observed in $T_{2}$ followed by $T_{6}$. Jawaharlal et al. (2001) [6] reported from their studies with hardened in vitro plantlets on standardization of growing media, cocopeat applied alone and in combination with leaf mould and FYM produced the highest number of branches and suckers / plant.
The plantlets in this media established well in terms of plant height in laboratory and in shade net (6.17 and 31.4 $\mathrm{cm}$ ) (Table 5) and number of new shootlets (Plantlet (2.67 and 7.67)) at laboratory and shade net condition (Table 6).

\begin{tabular}{|c|c|c|c|c|}
\hline Treatments & \multicolumn{2}{|c|}{ Stages } & \multicolumn{2}{c|}{ Stages } \\
\hline & Under laboratory condition & Under shade net & Under laboratory condition & Under shade net \\
\hline $\mathrm{T}_{1}$ & 8.67 & 17.33 & 1.33 & 5 \\
\hline $\mathrm{T}_{2}$ & 12.33 & 20.67 & 2.67 & 7.67 \\
\hline $\mathrm{T}_{3}$ & 6.33 & 12.67 & 1.33 & 3.7 \\
\hline $\mathrm{T}_{4}$ & 6 & 10.67 & 1.31 & 3.4 \\
\hline $\mathrm{T}_{5}$ & 6.67 & 11 & 0.67 & 2.67 \\
\hline Mean & 10.67 & 19 & 1.67 & 5.33 \\
\hline SE (d) & 8.6572 & 15.2367 & 1.5056 & 4.6828 \\
\hline CD (at 5\%) & 1.6422 & 1.6462 & 0.0688 & 0.1841 \\
\hline
\end{tabular}

Table 6: Effect of prehardening and hardening of media on number of leaves and number of shootlets of in vitro derived plantlets of Anthurium variety Temptation.

The number of leaves were highest in $\mathrm{T}_{2}$ (12.33 and 20.67) Chandrappa (2002) [7] and number of roots i.e., 3.33 and 8.33 / plant were higher in medium containing Leaf mould + Coco peat + Charcoal (1:1:1) followed by control i.e., $\mathrm{T}_{6}$ (Leaf mould + Coco peat (1:1)) (Table 6) [8].
The root length was also recorded higher in $\mathrm{T}_{2}$ (Leaf mould + Coco peat + Charcoal (1:1:1)) as $4.3 \mathrm{~cm}$ and 15.67 $\mathrm{cm}$ (Table 7) in laboratory and in shade net respectively.

\begin{tabular}{|c|c|c|c|c|}
\hline Treatments & \multicolumn{2}{|c|}{ Stages } & \multicolumn{2}{c|}{ Stages } \\
\hline & Under laboratory condition & Under shade net & Under laboratory condition & Under shade net \\
\hline $\mathrm{T}_{1}$ & 1.67 & 5 & 3.7 & 13.67 \\
\hline $\mathrm{T}_{2}$ & 3.33 & 8.33 & 4.3 & 15.67 \\
\hline $\mathrm{T}_{3}$ & 1.67 & 4.3 & 3.37 & 12.67 \\
\hline $\mathrm{T}_{4}$ & 1.33 & 3.3 & 2.93 & 10.33 \\
\hline $\mathrm{T}_{5}$ & 1.31 & 3.67 & 2.27 & 14.67 \\
\hline Mean & 2 & 5.67 & 4 & 12.6261 \\
\hline SE (d) & 1.8917 & 5.0511 & 3.4328 & 1.3416 \\
\hline CD (at 5\%) & 0.0796 & 0.1912 & 0.3646 & \\
\hline
\end{tabular}

Table 7: Effect of prehardening and hardening of media on number of roots and root length of in vitro derived plantlets of Anthurium variety Temptation.

\section{References}

1. Conner AJ, Thomas MB (1981) Reestablishing plantlets from tissue culture: a review. Combined Proceedings of the International Plant Propagators Society 31: 342-357.
2. Paul CA, Rajeevan PK (1992) Influence of media on growth parameters in Dendrobium. The Journal of the Orchid Society of India 6: 55-57.

3. Griffis JL, Hennen G, Oglesby PP (1983) Establishing tissue cultured plants in soil. Combined Proceedings of the International Plant Propagators Society 33: 618-622. 


\section{Open Access Journal of Agricultural Research}

4. Sharma A, Tabdon $P$ (1992) In vitro culture of Dendrobium wandianum Warner: Morphogenetic effects of some nitrogenous adjuvants. Indian J Plant Physiol 35(1): 80-85.

5. Abad M, Nouguera $P$, Puchades R, Maquieira A, Noguera V (2002) Physico-chemical and chemical properties of some coconut coir dusts for use as a peat substitute for containerized ornamental plants. Bioresour Technol 82(3): 241-245.

6. Jawaharlal (2001) Potting media for Vanda. Journal of ornamental Horticulture 4(1): 55-56.

7. Chandrappa (2002) Evaluation and effect of media, bio fertilizer and growth regulators on growth and flowering in anthuriums. Ph.D. Thesis, University of Agricultural Sciences, Bangalore.
8. Zaghloul MA, Alla H, Waly AK, Khattab SH (1996) Micropropagation of some ornamental plants. 2. In vitro culture, establishment and effect of potting mixture and NPK fertilization on ex vitro of Philodendron domesticum L. Annals of Agriculture Science, Moshtohor 34(2): 711-725.

9. Indhumadhi (2003) Standardization of prehardening and hardening techniques for in vitro derived plantlets of Dendrobium orchid. Journal of Ornamental Horticulture 6(3): 212-216.

10. Jawaharlal M, Joshua JP, Arumugam T, Subramanian S, Vijayakumar M (2001) Standardization of growing media for $A$. andreamum cv. Temptation under shadenet house. South Indian Horticulture, 49: 325328. 